\title{
The Turkish and Syrian Customers' Attitudes and Behaviors towards Islamic Banking in Turkey
}

\author{
Dania Farhoud ${ }^{*}$ \\ Şakir Görmüşs*
}

Received: 04.02.2021

Accepted: 10.03 .2021

DOI: $10.25272 /$ ijisef. 874545

Type: Research Article

\begin{abstract}
Day after day, the Competition in the banking sector increases; the customer perspective became significant element in the banking sector. This shows how important it is to determine the point of view and perceptions of the beneficiaries of Islamic banks. The study aims to examine Turks and Syrian customers' preference and behaviors to find out the reasons affect their choosing between Islamic and conventional banks in Turkey. According to the findings; age, occupation, and monthly income influence both Turkish and Syrian customers in Islamic banking preferences. However, the gender does not affect either Turkish or Syrian customers in their selection. Education was found to be an influencer factor for Syrian customers, but not for Turkish. However, after comparing the results of Turks and Syrians, Islamic banking selection-related differences were found between Turks and Syrians with regards to gender, education level, profession, and monthly income, but no age-related differences were found. The research results suggest that there is an effect of bank reputation, customer awareness, service quality, and employee behavior on the customers' preferences toward Islamic banking, whereas the religion factor neither affect Turks nor Syrians. The mass media in Turkey, however, affects the Turks; but does not affect Syrians.
\end{abstract}

Keywords: Islamic banking, Gender, Age groups, Education level, Occupation, Monthly income.

Jel Codes: G4, G20, G21

\footnotetext{
* Master Student, Sakarya University, dania.farhoud@ogr.sakarya.edu.tr, ORCID: 0000-0001-6541-494X

** Prof. Dr, Sakarya University, sgormus@sakarya.edu.tr, ORCID: 0000-0002-1857-8682
} 


\section{Introduction}

The competition in the banking industry is increasing; the customer perspective is becoming a more significant element in the banking sector. This makes it important to determine both perspective and behavior of the Islamic banks' current and potential customers. Islamic banks attract large numbers of customers by offering interest-free quality products and services rather than interest-based products. Nevertheless, Islamic banks still face difficulties in competing with conventional banks. Accordingly, it is very important to examine the factors affecting customers' preferences in choosing between conventional and Islamic banks.

Turkish Islamic banking system has 38 years of history and experience. Turkish Islamic banks started in 1985 with Albaraka Turk Participation Bank. Today, the Turkish financial system has 6 Islamic banks. In the recent years, the asset size of the Islamic banking sector has shown rapid development. Whereas Islamic banks in Syria are regarded as low experienced as it started operations in 2007 only with three Islamic banks only operating in Syria.

The study aims to examine Turks and Syrian customers' preference and behaviors to find out the reasons affect their choosing between Islamic and conventional banks in Turkey. Since there are 4 million Syrians live in Turkey today, this search examined both Turkish and Syrian customers' preference towards Islamic Banks in Turkey, and statistically analyzed collected data. The research also examined the data according to genders, age groups, education levels, occupations, and monthly income characteristics. The results compared preferences of Islamic and conventional banks between Turks and Syrians.

\section{Literature Review}

Customers play the most important role in the success of any organization, as they are the main stakeholder with all services are provided for their needs. Considering the strong competition between Islamic banks and conventional banks, each type seeks to gain more share in the market. However, many factors affect their success in attracting more shares as per different studies.

Abbasi et al. (2012) have attempted to examine customers' tendencies towards Islamic banking and awareness of Islamic banking services compared to traditional banking in the Bahawalpur region of Pakistan. In that study, both analytical and descriptive forms were used, and a comprehensive questionnaire was developed to collect data on a scale to evaluate the theoretical model. The sample size consists of 125 Islamic bank customers from 20 banks in the Bahawalpur region of Pakistan. According to their study results, they found that people in Bahawalpur are very interested in interest-free banking, but they do not have enough knowledge and awareness about the Islamic banking system. Islamic banking awareness has been found to play an important role in customers' preferences. Service quality, religious thinking, concreteness, and novelty factors have been found to have important criterion and motivating customers towards the acceptance of Islamic banking. 
Kaytanc1 et al. (2013) tried to analyze the awareness and satisfaction level among their customers of participation banks in Eskişehir. According to their study, they found that the advice of friends and relatives was the first reason why customers select any bank services in Turkey. On the other hand, they concluded that the religion factor did not play an important role in choosing a participation bank. However, they found that, in general, there is a high level of awareness customers have regarding the usage of the participation banks' products and services.

Toraman et al. (2015) tried to determine the preference and behavior of existing and potential customers towards Islamic banking activities. In their survey, the questionnaire form, using Szczepanowicz (2011) as a data collection tool, was applied Gaziantep. The questionnaire form consisted of two parts. In the first part, questions studied different characteristics of the participants and in the second part, 18 questions were designed to examine the participants' level of knowledge about Islamic banking and their preference and behavior towards Islamic banks. The number of participants of their questionnaire was 539. The techniques that were used in their study were: Pilot application, questionnaire application, and face to face questionnaire technique. It has been concluded that the most influencing factors on the potential customers are advertisement frequency, Islamic banking knowledge level, and religious motivation. On the other hands, it has been revealed that the awareness of potential customers of the Islamic banking system as an alternative to the conventional banking system, and of Islamic banking activities are so vulnerable.

Demirdöğen \& Özkul (2018) tried to examine the factors affecting the banking preference of customers in Isparta. The researchers investigated the importance of religious values and principles, having knowledge about Islamic finance, and knowing the differences between Islamic service providers and traditional banks on customer preferences. According to the study results, the society of Isparta Province did not find Islamic banking as an alternative to the conventional banking system and most of the participants do not know the differences between conventional banks and Islamic services providers. The researchers found that the reason for the low awareness of the participants about Islamic Banking was that participation banks were not well-known in the Province. But the researchers found that the remaining factors the participants' profession, age group, education group, and income group, in addition to the importance of religious values and principles and knowledge of Islamic finance, have a significant effect on customers in choosing an Islamic bank.

Tekin (2019) aimed to examine the university students' knowledge, perception and awareness levels and preferences regarding Islamic services participation banks. He analyzed students' various demographic characteristics, educational level and religious sensitivities on their perception and knowledge levels effects regarding participation banking. The research was on the students of Çankırı Karatekin University. In the research, a questionnaire was applied to 324 students in total. The results of the research found that the students do not have a sufficient level of knowledge and awareness about participation banking. However, it has been observed 
that the preference of participation banking differs according to the perception of them. It also has been observed that the religion factor can be a moderate factor in Islamic banking selection.

\section{Global Development of Islamic Finance and Banking}

The Islamic finance sector is growing more rapidly compared to the conventional finance sector in Islamic countries. In Islamic countries, there is increasing in the developments of macro data, Islamic banking's legal regulations, and the numbers of existing and potential customers. According to the latest reports, the Islamic finance industry around the world consists of 1,389 full-fledged institutions and Islamic windows. However, despite this rapid development of Islamic finance, the growth rate retreated between 2017-2018. According to Thomson Reuters Report 2019, The growth in the Islamic finance industry has fallen from $7 \%$ to $3 \%$ in 2018. Comparison with the previous year, total assets increased from $\$ 2.46$ Billion to $\$ 2.52$ Billion (Thomson Reuters Report, 2018).

Today, 520 Islamic banks operating in 72 countries around the world, most of which are commercial and 301 out of which full-fledged, while the other 219 are Islamic banking windows of conventional banks. Considered as the largest contributor in the Islamic finance industry, Islamic Banks hold 70\% of Islamic Finance' total assets. According to The Banker magazine, Islamic banks assets increased from \$1.304 billion in 2012 to $\$ 1.760$ billion in 2018 (Refinitiv, 2019).

In 2018, the top ten countries in total Islamic banking assets hold 95\% of all Islamic banking assets in the world. The leaders countries are Iran with $29.7 \%$, Saudi Arabia with $23.7 \%$, followed by Malaysia in third place with $13 \%$ and the United Arab Emirates in the fourth rank with $11.8 \%$ of the assets (Refinitiv, 2019).

\section{Islamic Banking in Syria}

The banking sector in Syria used to be historically limited to only six banks that were governed by the Central Bank of Syria and segmented according to the major area of focus as follows:

- $\quad$ Syrian Commercial Bank.

- Savings Bank.

- Popular Credit Bank.

- $\quad$ Real Estate Bank.

- $\quad$ Agricultural Cooperative Bank.

- Industrial Bank.

At the beginning of 2004, legislation was passed to allow private banks to start their operations in Syria. In 2005, legislation was passed to allow Islamic banks to start operations. There are fourteen private banks; three of which are Islamic banks. The first Islamic Bank operated in Syria was Sham Bank which was founded in 2007, followed by the Islamic Syrian International Bank, which was also established in 2007, and the last one was Baraka Bank, which started its 
operations in 2010. Today, Islamic Banks in Syria weigh 21.43\% of the Syrian banking sector. The number of Islamic bank branches reached 42 in 2011 and that represented 5\% of the total number of all the banking sector branches at that time. According to the Central Statistics Office, the table below shows the working Islamic banks in Syria and the number of their branches (Central Statistics Office Syria, 2011).

Table 1: Syria's Islamic Banks

\begin{tabular}{|c|c|c|}
\hline Bank Name & Bank Type & Number of Branches \\
\hline Sham Bank & full-fledged Islamic bank & 8 \\
\hline Islamic Syria International Bank & full-fledged Islamic bank & 25 \\
\hline Baraka Bank & full-fledged Islamic bank & 9 \\
\hline
\end{tabular}

\subsection{Islamic Banking Performance in Syria 2007-2018}

Between 2007-2018 Islamic banking share in the market did not improve as well as the conventional banks. From 2008 to 2010 , the average change in assets increased by $23 \%$, and the average change in deposits increased by $18 \%$. After Baraka Bank started its operations, the average change rate of assets increased by $24 \%$ and deposits decreased by $16 \%$ between 2010 and 2018 (Baraka Bank, 2018).

Islamic banks' assets volume is increased with an unstable rate. In 2009, the annual change rate of assets increased to $38.2 \%$ comparing to 2008 . However, this rate decreased to $25 \%$ in 2010 , it continued decreasing until 2011 to reach as low as 1\% only. The decline in Islamic banks assets is due to the political volatility in Syria that started in March 2011.

The Syrian Islamic banking deposits annual rate change increased to $44 \%$ in 2009 compared with 2008 while in 2010 it fell to 25\%. The annual rate change in deposits sharply fell in 2011 by $(-28 \%)$ and in 2015 by (-8\%) (Sham Bank, 2018; Islamic Syria International Bank, 2018)

\section{Islamic Banking in Turkey}

\subsection{The Historical Development of Islamic Banking in Turkey}

The Islamic banks in Turkey, called as interest-free Banks or participation banks, started their operations in the environment of the free-market economy and neo-liberal policies around the world. In 1975 Turkey joined the Islamic Development Bank with an 8.5\% share as a founding partner. In 1983, The government in Turkey legally allowed private financial institutions (interest-free banking institutions) to start their operations. Islamic financial institutions have started their work in Turkey due to the demand abundance for interest-free financing instruments and the lack of their resource. The Turkish Islamic banking historical development is shown below (Atar, 2017; Görmüş et al., 2019). 
Table 2: Historical Development of Islamic Banking

\begin{tabular}{|c|c|c|}
\hline Year & The Events & The Changes \\
\hline 1983 & $\begin{array}{l}\text { The legal basis of interest-free banking } \\
\text { was established. }\end{array}$ & 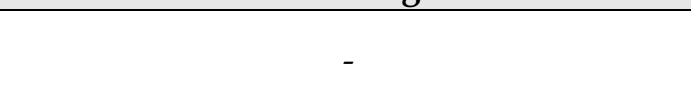 \\
\hline 1984 & $\begin{array}{l}\text { Albaraka Türk was established as the } \\
\text { first private Islamic financial institution. } \\
\text { Faisal Finance institution was } \\
\text { established and started its operations. }\end{array}$ & $\begin{array}{l}\text { Albaraka Türk was permitted to start its } \\
\text { operations in } 1985 . \\
\text { The name Faisal Finance corporation has } \\
\text { been changed to Family Finance Institution. }\end{array}$ \\
\hline 1989 & $\begin{array}{l}\text { Kuveyt Türk Participation Bank was } \\
\text { established }\end{array}$ & $\begin{array}{l}\text { Kuveyt Türk opened its foreign branch in } \\
\text { Bahrain in } 2002 \text {. }\end{array}$ \\
\hline 1991 & $\begin{array}{l}\text { Anadolu Finance corporation was } \\
\text { established with local capital in Ankara. }\end{array}$ & $\begin{array}{l}\text { In } 2005 \text { Anadolu Finance Institution and } \\
\text { Family Finance corporation merged under } \\
\text { the name Türkiye Finans Participation Bank. }\end{array}$ \\
\hline 1995 & $\begin{array}{l}\text { İhlas Finance corporation was } \\
\text { established. }\end{array}$ & $\begin{array}{l}\text { The İhlas Finance corporation went } \\
\text { bankrupt due to the economic crisis that } \\
\text { occurred in 2001, and it was closed by the } \\
\text { Banking Regulation and Supervision } \\
\text { Agency. }\end{array}$ \\
\hline 1996 & $\begin{array}{l}\text { Asya Finance Corporation was } \\
\text { established. }\end{array}$ & $\begin{array}{l}\text { The operating license of Asya Bank was } \\
\text { revoked by The Participation Banks } \\
\text { Association of Turkey in } 2016 \text {. }\end{array}$ \\
\hline 2000 & $\begin{array}{l}\text { The Banking Regulation and Supervision } \\
\text { Agency were established. }\end{array}$ & - \\
\hline 2001 & $\begin{array}{l}\text { The Special Finance Institutions } \\
\text { Association was established. }\end{array}$ & $\begin{array}{l}\text { In 2005, with the new banking law the } \\
\text { institutions' titles in the sector title were } \\
\text { changed to "participation bank" instead of } \\
\text { "private financial institutions", and "the } \\
\text { Association of Special Finance Institutions } \\
\text { Union" title was changed to " The } \\
\text { Participation Banks Association of Turkey". }\end{array}$ \\
\hline 2009 & $\begin{array}{l}\text { The first takaful company Neova was } \\
\text { established. }\end{array}$ & \\
\hline 2013 & $\begin{array}{l}\text { The first interest-free pension company } \\
\text { was established by Albaraka Türk and } \\
\text { Kuveyt Türk partnership. }\end{array}$ & \\
\hline 2015 & $\begin{array}{l}\text { Ziraat Participation } \\
\text { established as the first } \\
\text { participation bank. }\end{array}$ & \\
\hline 2016 & $\begin{array}{l}\text { Vakıf Participation bank was established } \\
\text { as the second public participation bank. }\end{array}$ & \\
\hline 2018 & $\begin{array}{l}\text { Participation Banks Association of } \\
\text { Turkey established the Central Advisory } \\
\text { Board. }\end{array}$ & \\
\hline 2019 & $\begin{array}{l}\text { The third public participation bank, } \\
\text { Emlak Participation Bank, was } \\
\text { established and started operations. }\end{array}$ & \\
\hline
\end{tabular}




\subsection{Islamic Banking Performance in Turkey 2007-2019}

In Turkey, six banks participate in Islamic banking operations, they carry out all kinds of banking activities in full compliance with interest-free banking principles. The following table shows the number of branches of Islamic banks operating in Turkey until 2019.

Table 3: Number of Participation Banks' Branches in Turkey

\begin{tabular}{|l|l|c|}
\hline \multicolumn{1}{|c|}{ Name of Bank } & \multicolumn{1}{|c|}{ Banks Type } & Number of Branches \\
\hline Albaraka Turk Participation Bank & Full Fledged Islamic bank & 229 \\
\hline Emlak Participation Bank & Full Fledged Islamic bank & 23 \\
\hline Kuveyt Turk Participation Bank & Full Fledged Islamic bank & 434 \\
\hline Türkiye Finans Participation Bank & Full Fledged Islamic bank & 311 \\
\hline Vakıf Participation Bank & Full Fledged Islamic bank & 111 \\
\hline Ziraat Participation Bank & Full Fledged Islamic bank & 104 \\
\hline
\end{tabular}

According to the latest reports in 2019, the total number of the six Islamic banks' domestic and overseas branches has increased by $5 \%$ compared to the previous year to reach 1179 branches. The Islamic banks' branches make up more than $10 \%$ of the banking sector branch network in the years $2007-2019$ (TBBK, 2019).

By the end of 2019, the share of Islamic banks held 6.3\% of the total assets of the banking sector. Between 2007-2019, the market share of Islamic banking in Turkey considerably developed. According to the Turkey Participation Banks Union 2019 reports, the asset size reached 284.459 Billion with a growth rate of $37.5 \%$, and the annual average growth rate was $28.74 \%$. While the size of the deposit reached 14.943 Billion TL with a growth rate of $57.02 \%$, and the annual average growth rate reached $25.91 \%$ (TBBK, 2019).

The Islamic banks' asset volume developed at an unstable rate between 2013 and 2016. The growth rate that was $36.70 \%$ in 2013 decreased to $8.40 \%$ in 2014 and turned up and to grow steadily to reach a growth rate of $20.50 \%$ in 2017 . The Islamic banks' deposit volume increased at an unstable rate between 2013 and 2016. As the growth rate was 27.59\% in 2013, decreased to $6.35 \%$ in 2014 and inverted back in 2017 to grow steadily to a growth rate of $29.20 \%$.

\section{Research Methodology}

\subsection{Research Design}

The study is based on quantitative data that was collected through a survey. The survey primary data were collected from randomly selected participants, but due to the emerging Coronavirus; the questionnaire was distributed over the internet. The questions in the survey segmented into two groups; actual questions and preferences and beliefs questions. Factual questions collected data about participants' gender, age, education level, marital status, profession, and income. The preferences and beliefs questions, however, were designed to collect data about participants' thoughts, believes or feelings towards Islamic banking. The survey was also designed to examine the differences between Syrian and Turkish customers' attitudes towards Islamic banking. The collected data were analyzed using the SPSS. 


\subsection{Survey Questionnaire}

The survey questionnaire was answered by 212 participants who were 'Islamic Banks' potential and existing customers. Nationalities of participants were Syrians (110) and Turks (102). All participants from both nationalities live in Turkey.

\subsection{Analytical Techniques}

In this study, descriptive analysis, Chi-Square Test, and T-test were used to measure whether the participants agree or agree with statements related to the Islamic banking issue. The purpose of using these analysis methods was to determine how do all participants perceived Islamic Banking.

\section{Data Analysis}

Descriptive statistics consist of procedures used to summarize and define the characteristics of participants in the survey data. Descriptive statistics of the study are presented in Table (4). The table illustrates the participants' gender, marital status, age, education level, occupation, and monthly income.

Table 4: The Participants Demographic Profile

\begin{tabular}{|c|c|c|c|c|c|}
\hline & & \multicolumn{2}{|c|}{ Turks } & \multicolumn{2}{|c|}{ Syrians } \\
\hline & & $\mathbf{F}$ & $\%$ & $\mathbf{F}$ & $\%$ \\
\hline \multirow{5}{*}{ Age Group } & $20-30$ & 34 & $33.3 \%$ & 42 & $38.2 \%$ \\
\hline & $31-40$ & 41 & $40.2 \%$ & 32 & $29.1 \%$ \\
\hline & $41-50$ & 22 & $21.6 \%$ & 28 & $25.5 \%$ \\
\hline & $51-60$ & 5 & $4.9 \%$ & 5 & $4.5 \%$ \\
\hline & 61 and Above & 0 & 0 & 3 & $2.7 \%$ \\
\hline \multirow{2}{*}{ Gender } & Woman & 63 & $61.8 \%$ & 39 & $35.5 \%$ \\
\hline & Man & 39 & $38.2 \%$ & 71 & $64.5 \%$ \\
\hline \multirow{2}{*}{ Marital Status } & Single & 42 & $41.2 \%$ & 40 & $36.4 \%$ \\
\hline & Married & 60 & $58.8 \%$ & 70 & $63.6 \%$ \\
\hline \multirow{5}{*}{ Education Level } & Less than High School & 1 & $1 \%$ & 0 & 0 \\
\hline & High School & 4 & $3.9 \%$ & 12 & $10.9 \%$ \\
\hline & Bachelor & 54 & $52.9 \%$ & 65 & $59.1 \%$ \\
\hline & Master & 34 & $33.3 \%$ & 20 & $18 \%$ \\
\hline & Doctorate & 9 & $8.8 \%$ & 13 & $12 \%$ \\
\hline \multirow{7}{*}{ Profession } & Employee & 52 & $51 \%$ & 39 & $35.5 \%$ \\
\hline & Worker & 11 & $10.8 \%$ & 2 & $1.8 \%$ \\
\hline & Self-Employment & 7 & $6.9 \%$ & 25 & $22.7 \%$ \\
\hline & Student & 23 & $22.5 \%$ & 20 & $18.2 \%$ \\
\hline & Job Seeker & 4 & $3.9 \%$ & 10 & $9.1 \%$ \\
\hline & Unemployment & 4 & $3.9 \%$ & 13 & $11.8 \%$ \\
\hline & Retired & 1 & $1 \%$ & 1 & $0.9 \%$ \\
\hline \multirow{5}{*}{$\begin{array}{l}\text { Monthly } \\
\text { Income }\end{array}$} & Less than 2250 & 30 & $29.4 \%$ & 38 & $34.5 \%$ \\
\hline & $2250-5000$ & 39 & $38.2 \%$ & 36 & $32.7 \%$ \\
\hline & $5000-7500$ & 22 & $21.6 \%$ & 13 & $11.8 \%$ \\
\hline & $7500-10000$ & 2 & $2 \%$ & 12 & $10.9 \%$ \\
\hline & 10000 and Above & 9 & $8.8 \%$ & 11 & $10.0 \%$ \\
\hline
\end{tabular}


The result of Turkish Participants' gender analysis shows that the participants are $61.8 \%$ females and $38.2 \%$ male. Participants' ages are 33.3\% in the age group $20-30,40.2 \%$ in the age group $31-40,21.2 \%$ in the age group $41-50$, and $4.9 \%$ in the age group 51-60. As for the marital status, it is shown that $58.8 \%$ of the respondents are married and $41.2 \%$ are single. As of the education level, results show that $1 \%$ of participants did not reach high school, $3.9 \%$ completed high school, 52.9\% hold bachelor's degree, 33.3\% hold master's degree and $8.8 \%$ hold a Doctorate. The participants' occupational status is: $51 \%$ employed, $10.8 \%$ workers, $6.9 \%$ selfemployed, $22.5 \%$ students, 3.9\% unemployed but seeking jobs, 3.9\% unemployed and not seeking jobs and $1 \%$ are retired. The monthly income levels groups of the respondents are: 29.4\% below $2250 \mathrm{TL}, 38.2 \%$ between $2250-5000$ TL, 21.6\% between 5500-7500 TL, $2 \%$ between 7500-10000 TL and 8.8\% earn more than 10000 per month.

Syrian Participants gender shows that the participants are $35.5 \%$ females and $64.5 \%$ males. Participants' age groups are: $38.2 \%$ in the $20-30$ age group, $29.1 \%$ in the $31-40$ age group, $25.5 \%$ in the $41-50$ age group and $4.5 \%$ in the $51-60$ age group. Marital status results are: $36.4 \%$ of the respondents are married and $64.5 \%$ are single. The Education level results show: $10.9 \%$ of participants completed studied high school, 59.1\% hold bachelor's degree, $18 \%$ hold a master's degree and $12 \%$ hold a Doctorate. The participants are distributed on the following occupational groups: $53.5 \%$ employees, $1.8 \%$ workers, $22.7 \%$ self-employed, $18.2 \%$ students, 9.1\% unemployed but seeking job, $11.8 \%$ unemployed but not seeking a job and $0.9 \%$ retired. As for the monthly income groups, results show 34.5\% earn below $2250 \mathrm{TL}, 32.7 \%$ earn between $2250-5000$ TL, $11.8 \%$ earn between $5500-7500$ TL, $10.9 \%$ earn between $7500-10000$ TL and $10 \%$ earn more than 10000 per month.

\subsection{The Customers' Selection of The Banking System}

Table 5: Participants' Preferences of Banking System

\begin{tabular}{|l|c|c|c|c|}
\hline \multirow{2}{*}{ Banking System } & \multicolumn{2}{c|}{ Turks } & \multicolumn{2}{c|}{ Syrian } \\
\cline { 2 - 5 } & F & $\%$ & F & $40 \%$ \\
\hline Islamic Banks & 32 & $31.4 \%$ & 44 & $30 \%$ \\
\hline Conventional Banks & 29 & $28.4 \%$ & 33 & $20 \%$ \\
\hline Islamic \& Conventional Banks & 27 & $26.5 \%$ & 22 & $10 \%$ \\
\hline None of Them & 14 & $13.7 \%$ & 11 & 4 \\
\hline
\end{tabular}

According to Table (5), $13.7 \%$ of 102 Turkish participants do not have any bank accounts, while $26.5 \%$ of them have accounts at both Islamic and Conventional banks, $31.4 \%$ have accounts in Islamic banks only, and $28.4 \%$ have accounts in conventional banks only.

The Syrian respondents, $10 \%$ do not have a bank account, $20 \%$ have accounts in both Islamic and conventional banks, $40 \%$ have accounts in Islamic banks only and 30\% have accounts in conventional banks only. 


\subsection{The Relationship Between Gender and Customers' Preference}

\subsubsection{The Relationship Between Gender and Banking System Preference}

Table 6: According to Gender the Participants Banking System Preferences

\begin{tabular}{|l|l|c|c|c|c|c|c|}
\hline \multirow{2}{*}{ Banking System } & \multicolumn{2}{c|}{ Women } & \multicolumn{2}{c|}{ Men } & \multicolumn{2}{c|}{ Total } \\
\cline { 2 - 7 } & & $\mathbf{S}$ & $\mathbf{\%}$ & $\mathbf{S}$ & $\mathbf{\%}$ & $\mathbf{S}$ & $\mathbf{\%}$ \\
\hline \multirow{4}{*}{ Turks } & Islamic & 20 & $63 \%$ & 12 & $38 \%$ & 32 & $31 \%$ \\
\cline { 2 - 8 } & Conventional & 17 & $59 \%$ & 12 & $41 \%$ & 29 & $28 \%$ \\
\cline { 2 - 8 } & Islamic \& Conventional & 14 & $52 \%$ & 13 & $48 \%$ & 27 & $27 \%$ \\
\cline { 2 - 8 } & None of Them & 12 & $86 \%$ & 2 & $14 \%$ & 14 & $14 \%$ \\
\hline \multirow{5}{*}{ Total } & 63 & $62 \%$ & 39 & $38 \%$ & 102 & $100 \%$ \\
\hline \multirow{5}{*}{ Syrian } & Islamic & 13 & $30 \%$ & 31 & $70 \%$ & 40 & $40 \%$ \\
\cline { 2 - 8 } & Conventional & 17 & $52 \%$ & 16 & $48 \%$ & 33 & $30 \%$ \\
\cline { 2 - 8 } & Islamic \& Conventional & 3 & $14 \%$ & 19 & $86 \%$ & 22 & $20 \%$ \\
\cline { 2 - 8 } & None of Them & 6 & $55 \%$ & 5 & $45 \%$ & 11 & $10 \%$ \\
\hline \multicolumn{2}{|c|}{ Total } & 39 & $35 \%$ & 71 & $65 \%$ & 110 & $100 \%$ \\
\hline
\end{tabular}

According to Table (6), after examining and comparing the gender information of Turkish participants, it is revealed that $63 \%$ of the participants prefer Islamic banks are women, and $38 \%$ are men. As for Participants who prefer conventional banks, 59\% of participants are women and $41 \%$ of them are men. Participants who prefer both Islamic and traditional banks, $52 \%$ of them are women and $48 \%$ of them are men. Finally, those who prefer neither Islamic banks nor traditional banks, $86 \%$ of them are women and $14 \%$ of them are men.

For Syrian participants, it is found that $30 \%$ of the participants prefer Islamic banks are women, and $70 \%$ are men. As for Participants who prefer conventional banks, 52\% of participants are women and $48 \%$ of them are men. Participants who prefer both Islamic and traditional banks, $14 \%$ of them are women and $86 \%$ of them are men. Finally, those who prefer neither Islamic banks nor traditional banks, $55 \%$ of them are women and $45 \%$ of them are men.

\subsubsection{Banking Preferences T-Test by Gender}

$\mathbf{H}_{0}$ : There is no statistically significant relationship between the two variables "Gender and Banking System Preference".

$\mathbf{H}_{1}$ : There is a statistically significant relationship between the two variables "Gender and Banking System Preference".

Table 7: T-Test by Gender

\begin{tabular}{|c|c|c|}
\hline T-Test & Turks & Syrian \\
\hline $\mathbf{t}$ & 0,740 & 0,379 \\
\hline $\mathbf{P}$ (Sig) & 0,461 & 0,693 \\
\hline $\mathbf{H}_{\mathbf{0}}$ & Accepted & Accepted \\
\hline
\end{tabular}


1- For Turkish customers: From Table $(7) \mathrm{P}(\mathrm{Sig})=0.461>0.05$, according to the T-test result $\mathrm{H}_{0}$ is accepted. So, there is no statistically significant relationship between variables "Gender and Banking System Preference". This means that gender has no effect on Turkish customers in selecting a banking system.

2- For Syrian customers: From Table (7) P (Sig) $=0.693>0.05$, according to the T-test result $\mathrm{H}_{0}$ is accepted. Thus, there is no statistically significant relationship between variables "Gender and Banking System Preference". This means that gender does not affect the Syrian customers in selecting a banking system in Turkey.

\subsubsection{The Relationship between Turkish and Syrians' preference in selecting Islamic banks by gender (T-Test)}

$\mathbf{H}_{0}$ : There is no relationship between Turkish and Syrian Islamic Banking Preferences by gender.

H1: There is a relationship between Turkish and Syrian Islamic Banking Preferences by gender.

Table 8: T-Test for Relationship between Turkish and Syrian by gender

\begin{tabular}{|c|c|}
\hline & Values \\
\hline $\mathbf{t}$ & $-4,012$ \\
\hline $\mathbf{P ( S i g )}$ & $<0,001$ \\
\hline $\mathbf{H}_{\mathbf{0}}$ & Denied \\
\hline
\end{tabular}

From the Table (8), $\mathrm{H}_{0}$ is rejected according to the T-test result as $\mathrm{P}(\mathrm{Sig})=0.001<0.05$. There is a statistically significant relationship between gender and Islamic Banking Preferences of Turkish and Syrians.

\subsubsection{The Relationship Between Age Group and Banking System Preferences}

Table 9: Participants' Banking System Preferences by Age Group

\begin{tabular}{|c|c|c|c|c|c|c|c|c|c|c|c|c|c|}
\hline & \multirow{2}{*}{$\begin{array}{l}\text { Banking } \\
\text { System }\end{array}$} & \multicolumn{2}{|c|}{$20-30$} & \multicolumn{2}{|c|}{$31-40$} & \multicolumn{2}{|c|}{ 41- 50} & \multicolumn{2}{|c|}{$51-60$} & \multicolumn{2}{|c|}{61 - over } & \multicolumn{2}{|c|}{ Total } \\
\hline & & S & $\%$ & S & $\%$ & $\mathrm{~S}$ & $\%$ & $S$ & $\%$ & S & $\%$ & S & $\%$ \\
\hline \multirow{4}{*}{$\begin{array}{l}\text { Tur } \\
\text { ks }\end{array}$} & Islamic & 9 & $28 \%$ & 12 & $38 \%$ & 10 & $31 \%$ & 1 & $3 \%$ & 0 & 0 & 32 & $31 \%$ \\
\hline & Conventional & 11 & $38 \%$ & 9 & $31 \%$ & 7 & $24 \%$ & 2 & $7 \%$ & 0 & 0 & 29 & $28 \%$ \\
\hline & $\begin{array}{l}\text { Islamic \& } \\
\text { Conventional }\end{array}$ & 3 & $11 \%$ & 19 & $70 \%$ & 3 & $11 \%$ & 2 & $7 \%$ & 0 & 0 & 27 & $26 \%$ \\
\hline & None of Them & 11 & $79 \%$ & 1 & $7 \%$ & 2 & $14 \%$ & 0 & 0 & 0 & 0 & 14 & $14 \%$ \\
\hline \multicolumn{2}{|c|}{ Total } & 34 & $33 \%$ & 41 & $40 \%$ & 22 & $22 \%$ & 5 & $5 \%$ & 0 & 0 & 102 & $100 \%$ \\
\hline \multirow{2}{*}{$\begin{array}{l}\text { Syr } \\
\text { ian }\end{array}$} & Islamic & 10 & $23 \%$ & 14 & $32 \%$ & 15 & $34 \%$ & 2 & $5 \%$ & 3 & $7 \%$ & 44 & $40 \%$ \\
\hline & Conventional & 22 & $67 \%$ & 4 & $12 \%$ & 6 & $18 \%$ & 1 & $3 \%$ & 0 & 0 & 33 & $30 \%$ \\
\hline
\end{tabular}




\begin{tabular}{|l|l|c|c|c|c|c|c|c|c|c|c|c|c|}
\hline & $\begin{array}{l}\text { Islamic \& } \\
\text { Conventional }\end{array}$ & 5 & $23 \%$ & 11 & $50 \%$ & 6 & $27 \%$ & 0 & 0 & 0 & 0 & 22 & $20 \%$ \\
\cline { 2 - 12 } & None of Them & 5 & $45 \%$ & 3 & $27 \%$ & 1 & $9 \%$ & 2 & $18 \%$ & 0 & 0 & 11 & $10 \%$ \\
\hline \multicolumn{2}{|l}{ Total } & 42 & $38 \%$ & 32 & $29 \%$ & 28 & $25 \%$ & 5 & $5 \%$ & 0 & 0 & 110 & $100 \%$ \\
\hline
\end{tabular}

According to Table (9), after examining and comparing the age group information of Turkish participants, participants who prefer Islamic banks; $28 \%$ of them are in the 20-30 age group, $38 \%$ of them are in the $31-40$ age group, $31 \%$ of them are in the $41-50$ age group, and $3 \%$ of them are in the 51-60 age group. As for participants who prefer conventional banks; $38 \%$ of them belong to the $20-30$ age group, $31 \%$ of them to the $31-40$ age group, $24 \%$ of them to the 41-50 age group, and $7 \%$ of them to the 51-60 age group. Speaking of participants who prefer both Islamic and traditional banks; $11 \%$ of them are in the $20-30$ age group, $70 \%$ of them are in the $31-40$ age group, $11 \%$ of them are in the $41-50$ age group, and $7 \%$ of them are in the $51-60$ age group. In respect of those who do not prefer any of the Islamic and traditional banks; $79 \%$ of them fall in the $20-30$ group, $7 \%$ of them fell in the $31-40$ group, and $14 \%$ of them fell in the 41-50 group.

As of Syrian participants, after examining and comparing their age group information, participants who prefer Islamic banks; $23 \%$ of them are in the $20-30$ age group, $32 \%$ of them are in the $31-40$ age group, $34 \%$ of them are in the $41-50$ age group, $5 \%$ of them are in the $51-$ 60 age group, and $7 \%$ of them are in the 61 and above age group. As for participants who prefer conventional banks; $67 \%$ of them belong to the $20-30$ age group, $12 \%$ of them to the 31 40 age group, $18 \%$ of them to the $41-50$ age group, and $3 \%$ of them to the $51-60$ age group. Speaking of participants who prefer both Islamic and traditional banks; $23 \%$ of them are in the $20-30$ age group, $50 \%$ of them are in the $31-40$ age group, and $27 \%$ of them are in the $41-50$ age group. In respect of those who do not prefer any of the Islamic and traditional banks; $45 \%$ of them fall in the $20-30$ group, $27 \%$ of them fell in the $31-40$ group, $9 \%$ of them fell in the $41-50$ group, and $18 \%$ of them fell in the 51-60 group.

\subsubsection{Chi-Square Test of Bank System Preference with Age Group}

$\mathbf{H}_{0}$ : There is no statistically significant relationship between the two variables "Age Group and Banking System Preference".

$\mathbf{H}_{1}$ : There is a statistically significant relationship between the two variables "Age Group and Banking System Preference".

Table 10: Chi-Square Test by Age Group

\begin{tabular}{|c|c|c|}
\hline Chi-Square Test & Turks & Syrian \\
\hline $\mathbf{X}^{\mathbf{2}}$ & $28.290^{\mathrm{a}}$ & $31.319^{\mathrm{a}}$ \\
\hline $\mathbf{P}($ Sig) & 0.001 & 0.002 \\
\hline $\mathbf{H}_{\mathbf{0}}$ & Denied & Denied \\
\hline
\end{tabular}


1- For Turkish customers: From Table (10) P (Sig) $=0.001<0.05$, according to the Chi-Square test result $\mathrm{H}_{0}$ is rejected. What it is mean There is a statistically significant relationship between the variables "Age Group and Banking System Preference". So, we can say that the age group influences Turkish customers in the banking system selection.

2- For Syrian customers: From Table (10) P (Sig) $=0.002<0.05$, according to the Chi-Square test result $\mathrm{H}_{0}$ is rejected. What it is mean There is a statistically significant relationship between the variables "Age Group and Banking System Preference". So, we can say that the age group influences Turkish customers in the banking system selection in Turkey.

6.2.2.2. The Relationship Between Turkish and Syrians' Preference in Selecting Islamic Banks by Age (Chi-Square Test)

$\mathbf{H}_{0}$ : There is no relationship between the Turkish and Syrians in the Islamic Banking Preferences according to age group.

$\mathbf{H}_{1}$ : There is a relationship between the Turkish and Syrians in the Islamic Banking Preferences according to age group.

Table 11: Chi-Square Test for Relationship between Turkish and Syrian by Age Group

\begin{tabular}{|c|c|}
\hline & Values \\
\hline $\mathbf{X}^{\mathbf{2}}$ & 5,684 \\
\hline $\mathbf{P}$ (Sig) & 0,224 \\
\hline $\mathbf{H}_{\mathbf{0}}$ & Accepted \\
\hline
\end{tabular}

From table (11) as $\mathrm{P}(\mathrm{Sig})=0.224>0.05, \mathrm{H}_{0}$ is accepted according to the Chi-Square result. That means there is no statistically significant relationship between Turkish and Syrians in Islamic Banking selection by age group.

\subsubsection{The Relationship between Education Level and Banking system Preferences:}

Table 12: The Participants' Banking System Preferences by Level of Education

\begin{tabular}{|c|c|c|c|c|c|c|c|c|c|c|c|c|c|}
\hline & \multirow[t]{2}{*}{$\begin{array}{l}\text { Banking } \\
\text { System }\end{array}$} & \multicolumn{2}{|c|}{$\begin{array}{c}\text { Less than } \\
\text { High } \\
\text { School }\end{array}$} & \multicolumn{2}{|c|}{$\begin{array}{l}\text { High } \\
\text { School }\end{array}$} & \multicolumn{2}{|c|}{ Bachelor } & \multicolumn{2}{|c|}{ Master } & \multicolumn{2}{|c|}{ Doctorate } & \multicolumn{2}{|c|}{ Total } \\
\hline & & $S$ & $\%$ & $\mathrm{~S}$ & $\%$ & $S$ & $\%$ & $S$ & $\%$ & $\mathrm{~S}$ & $\%$ & $\mathrm{~S}$ & $\%$ \\
\hline \multirow{4}{*}{ Turks } & Islamic & 0 & 0 & 1 & $3 \%$ & 15 & $47 \%$ & 10 & $31 \%$ & 6 & $19 \%$ & 32 & $31 \%$ \\
\hline & Conventional & 0 & 0 & 2 & $7 \%$ & 15 & $52 \%$ & 11 & $38 \%$ & 1 & $3 \%$ & 29 & $28 \%$ \\
\hline & $\begin{array}{l}\text { Islamic \& } \\
\text { Conventional }\end{array}$ & 0 & 0 & 0 & 0 & 14 & $52 \%$ & 11 & $41 \%$ & 2 & $7 \%$ & 27 & $26 \%$ \\
\hline & None of Them & 1 & $7 \%$ & 1 & $7 \%$ & 10 & $71 \%$ & 2 & $14 \%$ & 0 & 0 & 14 & $14 \%$ \\
\hline \multicolumn{2}{|l|}{ Total } & 1 & $1 \%$ & 4 & $4 \%$ & 54 & $53 \%$ & 34 & $33 \%$ & 9 & $9 \%$ & 102 & $100 \%$ \\
\hline \multirow{4}{*}{ Syrian } & Islamic & 0 & 0 & 0 & 0 & 25 & $57 \%$ & 11 & $25 \%$ & 8 & $18 \%$ & 44 & $40 \%$ \\
\hline & Conventional & 0 & 0 & 1 & $3 \%$ & 27 & $82 \%$ & 4 & $12 \%$ & 1 & $3 \%$ & 33 & $30 \%$ \\
\hline & $\begin{array}{l}\text { Islamic \& } \\
\text { Conventional }\end{array}$ & 0 & 0 & 7 & $32 \%$ & 6 & $27 \%$ & 5 & $12 \%$ & 4 & $18 \%$ & 22 & $20 \%$ \\
\hline & None of Them & 0 & 0 & 4 & $36 \%$ & 7 & $64 \%$ & 0 & 0 & 0 & 0 & 11 & $10 \%$ \\
\hline \multicolumn{2}{|l|}{ Total } & 0 & 0 & 12 & $11 \%$ & 65 & $59 \%$ & 20 & $18 \%$ & 13 & $12 \%$ & 110 & $100 \%$ \\
\hline
\end{tabular}


According to Table (12), by examining the Turkish participants' level of education data, we found that for those who prefer Islamic banks 3\% of them studied high school, $47 \%$ studied bachelor, $31 \%$ of them studied master, and $19 \%$ of them studied doctorate. As for those who prefer conventional banks, it is stated that $7 \%$ of them have a high school education, $52 \%$ have a bachelor's degree, $38 \%$ of them have a master's degree, and 3\% of them have a doctorate. Speaking of participants who are dealing with both Islamic and traditional banks; It is found that $52 \%$ of them have a bachelor's degree, $41 \%$ of them have a master's degree, and $7 \%$ of them have a doctorate. Whereas those who do not prefer either traditional banks or Islamic Banks; It is revealed that $7 \%$ of them studied less than high school, $7 \%$ of them studied high school, $71 \%$ of them studied bachelor, and $14 \%$ of them studied master.

As of Syrian participants who live in Turkey, after examining and comparing their level of education data, we found that for those who prefer Islamic banks 57\% studied bachelor, $25 \%$ of them studied master, and $18 \%$ of them studied doctorate. As for those who prefer conventional banks, it is stated that $3 \%$ of them have a high school education, $82 \%$ have a bachelor's degree, $12 \%$ of them have a master's degree, and $3 \%$ of them have a doctorate. Speaking of participants who are dealing with both Islamic and traditional banks; It is found that $19 \%$ of them have a high school education, $43 \%$ of them have a bachelor's degree, $24 \%$ of them have a master's degree, and $14 \%$ of them have a doctorate. Whereas those who do not prefer either traditional banks or Islamic Banks; It is revealed that $36 \%$ of them studied high school, and $64 \%$ of them studied bachelor.

\subsubsection{Chi-Square Tests for Education Level and Bank System Preferences}

$\mathbf{H}_{0}$ : There is no statistically significant relationship between the two variables "Education Level and Banking System Preference".

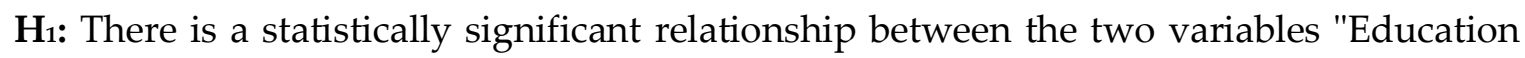
Level and Banking System Preference".

Table 13: Chi-Square by Education Level

\begin{tabular}{|c|c|c|}
\hline Chi-Square Test & Turks & Syrian \\
\hline $\mathbf{X}^{2}$ & $18.811^{\mathrm{a}}$ & $38.518^{\mathrm{a}}$ \\
\hline $\mathbf{P}$ (Sig) & 0.222 & 0.000 \\
\hline $\mathbf{H}_{\mathbf{0}}$ & Accepted & Denied \\
\hline
\end{tabular}

1- For Turkish customers from the table (13): as P (Sig) $=0.222>0.05$, according to the ChiSquare result $\mathrm{H}_{0}$ is accepted. It is founded that there is no statistically significant relationship between the variables "Education Level and Banking System Preference". This means that education level does not affect Turkish customers' preferences in selecting a banking system.

2- Speaking of Syrian customers who live in Turkey, from the table (13): as $\mathrm{P}(\mathrm{Sig})=0.000<0.05$, according to the Chi-Square result $\mathrm{H}_{0}$ is rejected. So, we can say that there is a statistically significant relationship between the variables "Education Level and Banking System 
Preference". This means that education level influences Syrian customers' preferences in selecting a banking system.

\subsubsection{The Relationship Between Turkish and Syrians' Preference in Selecting Islamic} Banks by Education Level (Chi-Square Test)

$\mathrm{H}_{0}$ : There is no relationship between the Turkish and Syrians in the Islamic Banking Preferences according to education level.

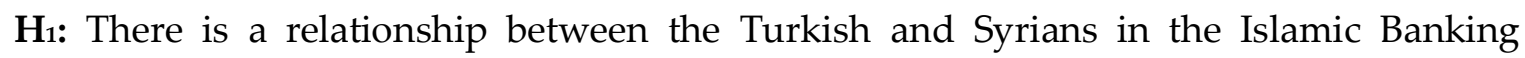
Preferences according to education level.

Table 14: Chi-Square Test for Relationship between Turkish and Syrian by Education Level

\begin{tabular}{|c|c|}
\hline & Values \\
\hline $\mathbf{X}^{2}$ & 37,484 \\
\hline $\mathbf{P ( S i g )}$ & $<0,001$ \\
\hline $\mathbf{H}_{0}$ & Denied \\
\hline
\end{tabular}

From table (14) as $\mathrm{P}(\mathrm{Sig})=0.001<0.05, \mathrm{H}_{0}$ is rejected according to the Chi-Square result. That means there is no statistically significant relationship between Turkish and Syrians in Islamic Banking selection by education level.

\subsubsection{The Relationship Between Occupation and Banking Preferences}

Table 15: Participants' Banking System Preferences by Occupation

\begin{tabular}{|c|c|c|c|c|c|c|c|c|c|c|c|c|c|c|c|c|c|}
\hline & \multirow{2}{*}{$\begin{array}{l}\text { Banking } \\
\text { System }\end{array}$} & \multicolumn{2}{|c|}{ Employee } & \multicolumn{2}{|c|}{ Worker } & \multicolumn{2}{|c|}{$\begin{array}{c}\text { Self- } \\
\text { employment }\end{array}$} & \multicolumn{2}{|c|}{ Student } & \multicolumn{2}{|c|}{$\begin{array}{c}\text { Job } \\
\text { Seeker }\end{array}$} & \multicolumn{2}{|c|}{$\begin{array}{c}\text { Un- } \\
\text { employed }\end{array}$} & \multicolumn{2}{|c|}{ Retired } & \multicolumn{2}{|c|}{ Total } \\
\hline & & $S$ & $\%$ & $\mathrm{~S}$ & $\%$ & $\mathrm{~S}$ & $\%$ & $\mathrm{~S}$ & $\%$ & $\mathrm{~S}$ & $\%$ & $S$ & $\%$ & S & $\%$ & S & $\%$ \\
\hline \multirow{4}{*}{ Turks } & Islamic & 16 & $50 \%$ & 1 & $3 \%$ & 2 & $6 \%$ & 9 & $28 \%$ & 2 & $6 \%$ & 2 & $6 \%$ & 0 & 0 & 32 & $31 \%$ \\
\hline & Conventional & 15 & $52 \%$ & 6 & $21 \%$ & 3 & $10 \%$ & 4 & $14 \%$ & 1 & $3 \%$ & 0 & 0 & 0 & 0 & 29 & $28 \%$ \\
\hline & $\begin{array}{l}\text { Islamic \& } \\
\text { Conventional }\end{array}$ & 20 & $74 \%$ & 4 & $15 \%$ & 1 & $4 \%$ & 0 & 0 & 0 & 0 & 1 & $4 \%$ & 1 & $4 \%$ & 27 & $26 \%$ \\
\hline & None of Them & 1 & $7 \%$ & 0 & 0 & 1 & $7 \%$ & 10 & $71 \%$ & 1 & $7 \%$ & 1 & $7 \%$ & 0 & 0 & 14 & $14 \%$ \\
\hline \multicolumn{2}{|l|}{ Total } & 52 & $51 \%$ & 11 & $11 \%$ & 7 & $7 \%$ & 23 & $23 \%$ & 4 & $4 \%$ & 4 & $4 \%$ & 1 & $1 \%$ & 102 & $100 \%$ \\
\hline \multirow{4}{*}{ Syrian } & Islamic & 16 & $36 \%$ & 0 & 0 & 15 & $34 \%$ & 6 & $14 \%$ & 3 & $7 \%$ & 3 & $7 \%$ & 1 & 2 & 44 & $40 \%$ \\
\hline & Conventional & 12 & $36 \%$ & 1 & $3 \%$ & 2 & $6 \%$ & 8 & $24 \%$ & 3 & $9 \%$ & 7 & $21 \%$ & 0 & 0 & 33 & $30 \%$ \\
\hline & $\begin{array}{l}\text { Islamic \& } \\
\text { Conventional }\end{array}$ & 9 & $41 \%$ & 0 & 0 & 8 & $36 \%$ & 3 & $14 \%$ & 2 & $9 \%$ & 0 & 0 & 0 & 0 & 22 & $20 \%$ \\
\hline & None of Them & 2 & $18 \%$ & 1 & $9 \%$ & 0 & 0 & 3 & $27 \%$ & 2 & $18 \%$ & 3 & $27 \%$ & 0 & 0 & 11 & $10 \%$ \\
\hline \multicolumn{2}{|l|}{ Total } & 39 & $35 \%$ & 2 & $2 \%$ & 25 & $23 \%$ & 20 & $18 \%$ & 10 & $9 \%$ & 13 & $12 \%$ & 1 & $1 \%$ & 110 & $100 \%$ \\
\hline
\end{tabular}

From the Table (15), after examining Turkish participants' occupation data, it is founded that those who prefer Islamic banks; $50 \%$ of them are employee, $3 \%$ of them are workers, $6 \%$ of them have their businesses, $28 \%$ of them are students, $6 \%$ of them are job seekers, and $6 \%$ of them are unemployed. As for those who prefer conventional banks, 52\% of them are 
employees, $21 \%$ of them are workers, $10 \%$ of them have their jobs, $14 \%$ of them are students, and $3 \%$ of them are job seekers. Those who prefer the two systems; $74 \%$ of them are employees, $15 \%$ of them are workers, $4 \%$ of them have their jobs, $4 \%$ of them are unemployed, and $4 \%$ of them are retired. For those who prefer neither Islamic banks nor traditional banks, it is revealed that $7 \%$ of them are employees, $7 \%$ of them have their jobs, $71 \%$ of them are students, $7 \%$ of them are job seekers, and $4 \%$ of them are unemployed.

As for the participants of the Syrians who prefer Islamic banks in Turkey; 63\% of them are employees, $34 \%$ of them have their businesses, $14 \%$ of them are students, $7 \%$ of them are job seekers, $7 \%$ of them are unemployed, and $2 \%$ of them are retired. When it comes to participants who prefer traditional banks; $36 \%$ of them are employees, $3 \%$ of them are workers, $6 \%$ of them have their businesses, $24 \%$ of them are students, $9 \%$ of them are job seekers, and $21 \%$ of them are unemployed. Speaking of those who prefer the two systems; $44 \%$ of them are employees, $36 \%$ of them have their businesses, $14 \%$ of them are students, and $9 \%$ of them are job seekers. Those who do not prefer both Islamic and conventional banks; $18 \%$ of them are employees, $9 \%$ of them are workers, $27 \%$ of them are students, $18 \%$ of them are job seekers, and $27 \%$ of them are unemployed.

\subsubsection{Chi-Square Tests for Occupation and Bank System Preferences}

$\mathbf{H}_{0}$ : There is no statistically significant relationship between the two variables "Occupation and Banking System Preference".

H1: There is a statistically significant relationship between the two variables "Occupation and Banking System Preference".

Table 16: Chi-Square Test by Occupation

\begin{tabular}{|c|c|c|}
\hline Chi-Square Test & Turks & Syrian \\
\hline $\mathrm{X}^{2}$ & $44.300^{\mathrm{a}}$ & $29.513^{\mathrm{a}}$ \\
\hline $\mathrm{P}(\mathrm{Sig})$ & 0.001 & 0.042 \\
\hline $\mathrm{H}_{0}$ & Denied & Denied \\
\hline
\end{tabular}

1- For Turkish customers from the table (16): as P (Sig) $=0.001>0.05$, according to the ChiSquare result $\mathrm{H}_{0}$ is rejected. It is founded that there is a statistically significant relationship between the variables " Occupation and Banking System Preference". This means that occupation affects Turkish customers' preferences in selecting a banking system.

2- Syrian customers who live in Turkey, from the table (16): as $\mathrm{P}(\mathrm{Sig})=0.042<0.05$, according to the Chi-Square result $\mathrm{H}_{0}$ is rejected. So, we can say that there is a statistically significant relationship between the variables "Occupation and Banking System Preference". This means that occupation influences Syrian customers' preferences in selecting a banking system.

\subsubsection{The Relationship Between Turkish and Syrians' Preference in Selecting Islamic Banks by Occupation (Chi-Square Test)}


$\mathbf{H}_{0}$ : There is no relationship between the Turkish and Syrians in the Islamic Banking Preferences according to the occupation.

$\mathbf{H}_{1}$ : There is a relationship between the Turkish and Syrians in the Islamic Banking Preferences according to the occupation.

Table 17: Chi-Square Test for Relationship between Turkish and Syrian by Occupation

\begin{tabular}{|c|c|}
\hline & Values \\
\hline $\mathbf{X}^{2}$ & 23,335 \\
\hline $\mathbf{P}($ Sig) & $<0,001$ \\
\hline $\mathbf{H}_{0}$ & Denied \\
\hline
\end{tabular}

From the table (17), as $\mathrm{P}(\mathrm{Sig})=0.001<0.05$ and according to the Chi-Square result $\mathrm{H}_{0}$ is rejected. That is mean that there is a statistically significant relationship between the Turkish and Syrians in the Islamic Banking selection by occupation.

\subsubsection{The Relationship between Monthly Income and Banking Preferences}

Table 18: The Participants' Banking Preferences by Monthly Income

\begin{tabular}{|c|c|c|c|c|c|c|c|c|c|c|c|c|c|}
\hline & \multirow{2}{*}{$\begin{array}{l}\text { Banking } \\
\text { System }\end{array}$} & \multicolumn{2}{|c|}{$\begin{array}{c}\text { Less than } \\
2250\end{array}$} & \multicolumn{2}{|c|}{$2250-5000$} & \multicolumn{2}{|c|}{$5000-7500$} & \multicolumn{2}{|c|}{$7500-10000$} & \multicolumn{2}{|c|}{$\begin{array}{c}\text { Above } \\
10000\end{array}$} & \multicolumn{2}{|c|}{ Total } \\
\hline & & $\mathrm{S}$ & $\%$ & $S$ & $\%$ & $S$ & $\%$ & $S$ & $\%$ & $\mathbf{S}$ & $\%$ & $S$ & $\%$ \\
\hline \multirow{4}{*}{ Turks } & Islamic & 11 & $34 \%$ & 12 & $38 \%$ & 8 & $25 \%$ & 0 & 0 & 1 & $3 \%$ & 32 & $31 \%$ \\
\hline & Conventional & 6 & $21 \%$ & 13 & $45 \%$ & 7 & $24 \%$ & 0 & 0 & 3 & $10 \%$ & 29 & $28 \%$ \\
\hline & $\begin{array}{l}\text { Islamic \& } \\
\text { Conventional }\end{array}$ & 1 & $4 \%$ & 13 & $48 \%$ & 7 & $26 \%$ & 2 & $7 \%$ & 4 & $15 \%$ & 27 & $26 \%$ \\
\hline & $\begin{array}{l}\text { None of } \\
\text { Them }\end{array}$ & 12 & $86 \%$ & 1 & $7 \%$ & 0 & 0 & 0 & 0 & 1 & $7 \%$ & 14 & $14 \%$ \\
\hline \multicolumn{2}{|l|}{ Total } & 30 & $29 \%$ & 39 & $38 \%$ & 22 & $22 \%$ & 2 & $2 \%$ & 9 & $9 \%$ & 102 & $100 \%$ \\
\hline \multirow{4}{*}{ Syrian } & Islamic & 8 & $18 \%$ & 12 & $27 \%$ & 9 & $20 \%$ & 7 & $16 \%$ & 8 & $18 \%$ & 44 & $40 \%$ \\
\hline & Conventional & 16 & $48 \%$ & 14 & $42 \%$ & 2 & $6 \%$ & 1 & $3 \%$ & 0 & 0 & 33 & $30 \%$ \\
\hline & $\begin{array}{l}\text { Islamic \& } \\
\text { Conventional }\end{array}$ & 6 & $27 \%$ & 8 & $36 \%$ & 1 & $5 \%$ & 4 & $18 \%$ & 3 & $14 \%$ & 22 & $20 \%$ \\
\hline & $\begin{array}{l}\text { None of } \\
\text { Them }\end{array}$ & 8 & $73 \%$ & 2 & $18 \%$ & 1 & $9 \%$ & 0 & 0 & 0 & 0 & 11 & $10 \%$ \\
\hline \multicolumn{2}{|l|}{ Total } & 38 & $35 \%$ & 36 & $33 \%$ & 13 & $12 \%$ & 12 & $11 \%$ & 11 & 10 & 110 & $100 \%$ \\
\hline
\end{tabular}

From the Table (18), after examining and comparing the monthly income information of Turkish participants, for those who prefer Islamic banks; It is stated that $34 \%$ of them receive a salary less than $2250,38 \%$ of them receive a salary between $2250-5000,25 \%$ of them receive a salary between $5000-7500$ and $3 \%$ of them received more than 10000 . As for participants who prefer conventional banks; $21 \%$ of receive a monthly salary less than $2250,45 \%$ of them receive a monthly salary between $2250-5000,7 \%$ of them receive a monthly salary between $5000-7500$, and $3 \%$ of them receive a salary more than 10000 monthly. Speaking of those who prefer the two systems; $4 \%$ of them have a monthly salary less than $2250,48 \%$ of them have a monthly salary $2250-5000,26 \%$ of them have a monthly salary $5000-7500,7 \%$ of them have a monthly 
salary $7500-10000$ and $15 \%$ to have more than 10000 . At the least for those who do not prefer any of the Islamic of traditional banks; It is stated that $86 \%$ of them receive a monthly salary less than $2250,7 \%$ of them receive a monthly salary between $2250-5000$ and $7 \%$ of them receive a monthly salary more than 10000 .

From the Table (18), after examining and comparing the monthly income information of Syrian participants, for those who prefer Islamic banks; It is stated that $18 \%$ of them receive a salary less than $2250,27 \%$ of them receive a salary between $2250-5000,20 \%$ of them receive a salary between $5000-7500,16 \%$ of them receive a salary between $7500-1000$, and $3 \%$ of them received more than 10000 . As for participants who prefer conventional banks; $48 \%$ of receive a monthly salary less than $2250,42 \%$ of them receive a monthly salary between $2250-5000,6 \%$ of them receive a monthly salary between $5000-7500$, and $3 \%$ of them receive a monthly salary between 7500-1000. Speaking of those who prefer the two systems; $27 \%$ of them have a monthly salary less than $2250,36 \%$ of them have a monthly salary $2250-5000,5 \%$ of them have a monthly salary $5000-7500,18 \%$ of them have a monthly salary $7500-10000$ and $14 \%$ to have more than 10000. At the least for those who do not prefer any of the Islamic of traditional banks; It is stated that $73 \%$ of them receive a monthly salary less than $2250,18 \%$ of them receive a monthly salary between $2250-5000$, and $9 \%$ of them receive a monthly salary between 5000-7500.

\subsubsection{Chi-Square Tests for Monthly Income and Bank System Preferences}

$\mathbf{H}_{0}$ : There is no statistically significant relationship between the two variables "Monthly Income and Banking System Preference".

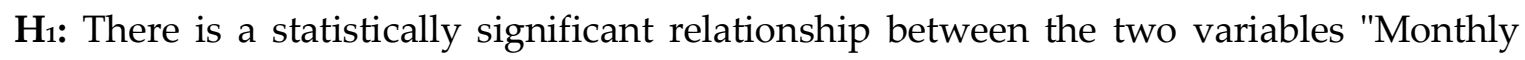
Income and Banking System Preference".

Table 19: Chi-Square Test by Monthly Income

\begin{tabular}{|c|c|c|}
\hline Chi-Square Test & Turks & Syrian \\
\hline $\mathbf{X}^{2}$ & $38.215^{\mathrm{a}}$ & $29.939^{\mathrm{a}}$ \\
\hline $\mathbf{P}($ Sig) & 0.000 & 0.003 \\
\hline $\mathbf{H}_{0}$ & Denied & Denied \\
\hline
\end{tabular}

1- For Turkish customers: from the table (19), as P (Sig) $=0.000<0.05$ according to the ChiSquare result $\mathrm{H}_{0}$ is rejected. Which means that there is a statistically significant relationship between variables "Monthly Income and Banking System Preference". So, we can say that the monthly income influences Turkish customers' in selecting the banking system.

2- For Syrian customers: from the table (19), as $\mathrm{P}(\mathrm{Sig})=0.003<0.05$ according to the Chi-Square result $\mathrm{H}_{0}$ is rejected. Which means that there is a statistically significant relationship between variables "Monthly Income and Banking System Preference". So, we can say that the monthly income influences Syrian customers' in selecting the banking system. 


\subsubsection{The Relationship Between Turkish and Syrians' Preference in Selecting Islamic Banks by Monthly Income (Chi-Square Test)}

$\mathbf{H}_{0}$ : There is no relationship between the Turkish and Syrians in the Islamic Banking Preferences according to the monthly income.

$\mathbf{H}_{1}$ : There is a relationship between the Turkish and Syrians in the Islamic Banking Preferences according to the monthly income.

Table 20: Chi-Square Test for Relationship between Turkish and Syrian by Monthly Income

\begin{tabular}{|c|c|}
\hline & Values \\
\hline $\mathbf{X}^{2}$ & 9,829 \\
\hline $\mathbf{P}($ Sig) & 0,043 \\
\hline $\mathbf{H}_{\mathbf{0}}$ & Denied \\
\hline
\end{tabular}

From Table (20), as $\mathrm{P}(\mathrm{Sig})=0.043<0.05$, and according to the Chi-Square result $\mathrm{H}_{0}$ is rejected. That means that there is a statistically significant relationship between monthly income and Islamic Banking Preferences of Turkish and Syrians.

\subsection{The Customers' Main Reasons for Selecting Islamic Banking}

Table 21: Customers' Main Reasons in Preferring Islamic Banking

\begin{tabular}{|c|c|c|c|c|c|c|c|c|}
\hline \multirow{2}{*}{$\begin{array}{l}\text { Main } \\
\text { Factors }\end{array}$} & \multicolumn{4}{|c|}{ Turks } & \multicolumn{4}{|c|}{ Syrian } \\
\hline & $\mathbf{F}$ & $\%$ & $\begin{array}{c}\text { Weighted } \\
\text { Average }\end{array}$ & Result & $\mathbf{F}$ & $\%$ & $\begin{array}{l}\text { Weighted } \\
\text { Average }\end{array}$ & Result \\
\hline $\begin{array}{l}\text { Religion } \\
\text { Factor }\end{array}$ & 78 & $76.5 \%$ & 2.2451 & Undecided & 63 & $57.3 \%$ & 2.2477 & Undecided \\
\hline $\begin{array}{c}\text { Bank } \\
\text { Reputation }\end{array}$ & 7 & $6.9 \%$ & 2.7941 & Positive & 24 & $21.8 \%$ & 2.8682 & Positive \\
\hline $\begin{array}{c}\text { Customer } \\
\text { Awareness }\end{array}$ & 17 & $16.7 \%$ & 2.5894 & Positive & 23 & $20.9 \%$ & 2.7353 & Positive \\
\hline
\end{tabular}

From the Table (21), it is shown that $76.5 \%$ of the Turkish participants' main reason for choosing Islamic banking is the religion factor. However, the religion factor is revealed to be unstable by participants according to its weighted average of 2.2451. The bank reputation is chosen as the main factor just by $6.9 \%$ of the participants. Whereas according to the bank reputation factor' weighted average of 2.7941; it was found as a positive factor by the participants. The customer awareness factor is considered as the main factor just by $16.7 \%$ of the participants. However, according to its weighted average of 2.5894; it is concluded as a positive factor.

From the Table (21), it is shown that $57.3 \%$ of the Syrian participants' main reason for choosing Islamic banking is the religion factor. However, the religion factor is revealed to be unstable by participants according to its weighted average of 2,2477 . The bank reputation is chosen as the main factor just by $21.8 \%$ of the participants. Whereas according to the bank reputation 
factor' weighted average of 2.8682; it was found as a positive factor by the participants. The customer awareness factor is considered as the main factor just by $20.97 \%$ of the participants. However, according to its weighted average of 2.7353, it is concluded as a positive factor.

\subsection{The Customers' Secondary Reasons for Selecting Islamic Banking}

Table 22: Customers' Secondary Reasons in Preferring Islamic Banking

\begin{tabular}{|l|c|c|c|c|c|c|c|c|}
\hline \multirow{2}{*}{ Main Factors } & \multicolumn{4}{|c|}{ Turks } & \multicolumn{4}{|c|}{ Syrian } \\
\cline { 2 - 9 } & $\mathbf{F}$ & $\%$ & $\begin{array}{c}\text { Weighted } \\
\text { Average }\end{array}$ & Result & $\mathbf{F}$ & $\%$ & $\begin{array}{c}\text { Weighted } \\
\text { Average }\end{array}$ & Result \\
\hline Service Quality & 60 & $58.8 \%$ & 2.9324 & Positive & 60 & $54.5 \%$ & 2.9682 & Positive \\
\hline $\begin{array}{l}\text { Employees } \\
\text { Behavior }\end{array}$ & 25 & $24.5 \%$ & 2.96363 & Positive & 35 & $31.8 \%$ & 2.9420 & Positive \\
\hline Mass Media & 17 & $16.7 \%$ & 2.7784 & Positive & 14 & $12.7 \%$ & 2.1909 & Undecided \\
\hline
\end{tabular}

From the Table (20), it is shown that $58.8 \%$ of the Turkish participants' secondary reason for choosing Islamic banking is the service quality factor. It is also revealed the service quality factor to be positive by participants according to its weighted average of 2,2477 . The employees' behavior chosen as the main factor just by $25.5 \%$ of the participants. Whereas according to the employees' behavior factor' weighted average of 2.96363; it was found as a positive factor by the participants. The Mass Media factor is considered as the secondary factor just by $16.7 \%$ of the participants. However, according to its weighted average of 2.5894; it is concluded as a positive factor.

From the Table (20), it is shown that $54.5 \%$ of the Syrian participants' main reason for choosing Islamic banking is the service quality factor. It is also revealed the service quality factor to be positive by participants according to its weighted average of 2,2477. The employees' behavior is chosen as the main factor just by $31.8 \%$ of the participants. Whereas according to the employees' behavior factor' weighted average of 2.9420; it was found as a positive factor by the participants. The Mass Media factor is considered as the main factor just by $12.7 \%$ of the participants. However, according to its weighted average of 2.1909, it is concluded as an unstable factor.

\section{Conclusions \& Results}

After analyzing and comparing the gender information of the respondents, it is concluded that $58 \%$ of Turkish respondents who prefer Islamic banking are female, while $76 \%$ of Syrian respondents are male. To know whether there is a statistically significant relationship between the two variables "Gender and Banking System Preference", the collected data was analyzed by using the T-Test. According to the T-Test values (Turkish P (sig) 0.461>0.05, Syrian P (sig) $0.693>0.05)$, gender does not affect the banking system preference when focusing on each nationality separately.

However, when applying T-Test on the differences between Turkish and Syrians' preference of Islamic banking according to gender, results of the T-Test value P (sig) was found to be 0.001 
$<0.05$, this indicates that there is a gender-related preference difference between Turkish and Syrians. The reason for that difference is suggested to be caused by the cultural differences between the Turkish and Syrian peoples. For instance, the unemployment rate for Syrian women is much higher than Turkish women.

After examining and comparing the participants' age groups statistical data, it was found that the highest age group rate among respondents who prefer Islamic banks is the $31-40$ age group. This is derived from the results that show 53\% of Turkish respondents and $38 \%$ of Syrian respondents who prefer Islamic banking are from the 31-40 group. So, to find if there is a statistically significant relationship between the two variables "Age Group and Banking System Preference" the Chi-square Test has been used. As the values of the Chi-Square test are for Turkish $\mathrm{P}(\mathrm{sig}) 0.001<0.05$, and for Syrian $\mathrm{P}(\mathrm{sig})=0.002<0.05$, which suggests that the age affects both Syrian and Turkish customers in the banking system preference. Considering the statistics above, one can argue that the age group is also related to other factors, for instance; education level and employment, suggestions that the age group in question is more educated with higher employment rate which results more awareness of and need for Islamic Banking Services.

When applying the Chi-Square test, the Chi-Square test value $\mathrm{P}(\mathrm{sig})$ was found to be $0.224>0.05$, this suggests that there are no age differences between Turkish and Syrians.

When analyzing and comparing the education level information of the respondents, it was found that $49 \%$ of Turkish and $47 \%$ of Syrian respondents who prefer Islamic banks hold a bachelor's degree. So, to find if there is a statistically significant relationship between the two variables "Education Level and Banking System Preference" the Chi-square Test has been applied. As the Chi-Square test value for Turks is (P (sig) $0.222>0.05$ ), this means that the education level does not affect Turkish customers preference for selecting a banking system. However, the Chi-Square test value for Syrian is $(\mathrm{P}(\mathrm{sig}) 0,000<0,05)$ shows that the education level is an affecting factor on Syrian customers when selecting the banking system. As for the relationship by education level between Turkish and Syrians' in Islamic banking selection, the Chi-Square test was applied to find out if there is a relationship or not. As the Chi-Square test shows a value of $\mathrm{P}(\mathrm{sig})$ is $0,001<0,05$, it can be concluded that there is an education-level related difference between Turkish and Syrians when selecting Islamic banking.

After analyzing and comparing the occupation information of the respondents, it was found that $61 \%$ of Turkish and $38 \%$ of Syrian respondents who select Islamic banks are employees. The Chi-square Test has been used to find if there is a statistically significant relationship between the two variables "Occupation and Banking System Preference". As the Chi-Square test values are (P (sig) $0,001<0,05$ for Turks and $\mathrm{P}(\mathrm{sig}) 0,042<0,05$ for Syrian), it is revealed that the profession affects Turkish and Syrian customers in the banking system preferences.

When the Chi-Square test was applied, however, to find out if there is a relationship by occupation between Turkish and Syrians' in selecting Islamic banking. As the Chi-Square test 
value $\mathrm{P}(\mathrm{sig})$ is $0,001<0,05$, that result suggests that there is a profession-related difference between Turkish and Syrians in Islamic banking selection.

After analyzing and comparing the income information of the respondents, it was found that $61 \%$ of Turkish and $38 \%$ of Syrian respondents who select Islamic banks have a monthly income between 2250-5000. The Chi-square Test has been used to find if there is a statistically significant relationship between the two variables "Monthly Income and Banking System Preference". As the Chi-Square test values are ( $\mathrm{P}$ (sig) 0,000<0,05 for Turks and $\mathrm{P}(\mathrm{sig})$ $0,003<0,05$ for Syrian), it is revealed that the monthly income affects Turkish and Syrian customers in the banking system preferences.

When applying Chi-Square test to find out if there is a relationship or not, Chi-Square test value result was $\mathrm{P}(\mathrm{sig}) 0,043<0,05$, This means that there are income-related differences between Turkish and Syrian in Islamic banking selection.

The religion factor has been chosen by $76.5 \%$ of the Turkish participants and $57.3 \%$ of the Syrian participants as one of the main reasons for choosing Islamic banking. On the other hand, the total weighted average of the religious factor of the participants was revealed to be (2.2451) for Turks and (2.2477) for Syrians. This suggests that participants are neutral when it comes to the compliance with Sharia principles in comparing to the factor's weighted average. This means the lack of customer confidence in the Islamic banks' work regarding complying with Sharia principles. This also means that religious motivation does not affect customers in their selection of Islamic banking system.

The bank reputation factor, however, was found to be chosen by $6.9 \%$ of the Turkish participants and $21.8 \%$ of the Syrian participants as one of the main reasons for choosing Islamic banking. As the total weighted average of the bank reputation factor of the participants was revealed to be $(2.7941)$ for Turks and $(2,8682)$ for Syrians, therefore, the bank reputation factor is a positive factor according to its weight average. It is concluded that the reputation factor of the Islamic bank is an effective motivation for customers to choose Islamic banking. The customer awareness factor has been chosen by $16.7 \%$ of the Turkish participants and $20,79 \%$ of the Syrian participants as one of the reasons for choosing Islamic banking. As the total weighted average of the customer awareness factor of the participants was revealed to be (2.5894) for Turks and (2.7353) for Syrians, therefore, the awareness factor is a positive factor according to its weight average. It is revealed that the customer awareness factor of the Islamic bank is an effective motivation factor for customers in choosing Islamic banking.

As for the secondary reasons for choosing Islamic banks, 58.8\% of Turks and 54.5\% of Syrians participants choose the service quality as one of the secondary reasons for choosing an Islamic bank. It was found that the total weighted average of the service quality factor of the participants was revealed to be $(2,9324)$ for Turks and $(2,9682)$ for Syrians. Therefore, it is concluded that the service quality factor is a positive factor according to its weight average, which means that the service quality factor is an effective motivation factor for customers in choosing Islamic banking. 
Regarding the employee behavior factor, $25.5 \%$ of Turks and $31.8 \%$ of Syrians participants choose the employee behavior factor as one of the secondary reasons for choosing an Islamic bank. The total weighted average of the employee behavior factor of the participants was revealed to be (2.96363) for Turks and (2.9420) for Syrians. This means that customers consider the employees' behavior factor as an important factor when choosing Islamic banks.

Finally, regarding the mass media factor, $16.7 \%$ of Turks and $12.7 \%$ of Syrians participants choose the mass media factor as one of the secondary reasons for choosing an Islamic bank. The total weighted average of the mass media factor of the participants was revealed to be (2.5894) for Turks and (2.1909) for Syrians, which means that the mass media factor is effective on Turkish customers, but it is not on Syrian customers in Islamic banking preferences. This difference between Syrians and Turks is suggested to be caused by the language barrier and the fact that all the ads are in the Turkish language. 


\section{References}

Abbasi, M.,Naeem, M., Saeed, Muhammad, R., (2012). The Tendency of Customers Towards the Acceptance of Islamic Banking in Bahawalpur Region, Pakistan. Research Journal of Finance and Accounting, 3(3).

Al-Baraka Bank, (2018). Annual Financial Reports. Consolidated Financial Statements. Retrieved from https:/www.albaraka.com/en/AboutUs/FinancialHighlights/16/annual-report.

Atar, A. (2017). From the Past to the Present the General Situation of Islamic Banking in the World and Turkey. History, Culture and Art Studies Journal, 1048 - 1055. DOI: 10.7596/taksad.v6i4.1079.

Demirdöğen, Y., Özkul, G., Bankacılık İşlemlerinde Katılım Bankaları Tercihini Etkileyen Faktörler: Isparta Örneği, Katılım Finans , Ankara: Gazi Kitabevi, 2018.

Görmüş, S. Albayrak, A. \& Yabanlı, A. (2019). Explaining the Turkish Islamic banking historical development. Yaşayan ve Gelişen Katılım Bankacılğı. TKBB Yayınları.

Refinitiv, (2019). Shifting Dynamics. Islamic Finance Development Report. Islamic Finance Overview. Retrieved January 27, 2020, from https://www.refinitiv.com/en/islamicfinance.

Islamic Syria International Bank, (2018). Annual Financial Reports. Consolidated Financial Statements. Retrieved from https://www.siib.sy/en/investor-relations/financialstatements.

Kaytanc1, B. G. Ergeç, E. H. \& Toprak, M. (2013). The Banking System Preferences of Participation Bank Customers: Islamic Banking Window for Deposit Banks. International Conference on Eurasian Economies.

Sham Bank, (2018). Annual Financial Reports. Consolidated Financial Statements. Retrieved January 20, 2020, from https://www.chambank.sy/en/about/financial-statments.

Syrian Central Statistics Office (2011). Statistical Abstract. Retrieved January 27, 2020, from http://cbssyr.sy/index-EN.htm

Tekin, B. (2019). The Effect of University Students' Preferences, Perception and Awareness Levels on Participation Banking. Journal of the International Scientific Research, 4(1). 10.21733/ibad.496489.

Thomson Reuters, (2019). Building Momentum. Islamic Finance Development Report. Retrieved January 27, 2020, from https://www.salaamgateway.com/reports.

TKBB, (2019). TKBB Annual Sector Reports. Participation Banks. Financial Statements and Data. Retrieved January 27, 2020, from https://tkbb.org.tr/Documents/Yonetmelikler/TKBB_AR19.pdf. 
Toraman, C , Ata, H , Buğan, M . (2015). A Study on Customer Perception towards the Islamic Banking Operations. Gaziantep University Journal of Social Sciences, 14(4) , 761-779 . DOI: $10.21547 /$ jss.256749 